\title{
Relative Sensitivity of Conventional Soybean to Three Dicamba Based Herbicides at Different Growth Stages
}

\author{
Stevan Z. Knezevic, Adewale O. Osipitan, Jon E. Scott \\ University of Nebraska - Lincoln, Lincoln, NE, USA \\ sknezevic2@unl.edu
}

SUMMARY

Widespread use of dicamba-based herbicides such as Clarity" (dicamba diglycolamine salt, $480 \mathrm{~g} \mathrm{l}^{-1}$ ), Engenia (dicamba N,N-Bis-[3-aminopropyl] methylamine salt, $600 \mathrm{~g} \mathrm{l}^{-1}$ ) and XtendiMax (dicamba diglycolamine salt, $350 \mathrm{gl}^{-1}$ ) with Vapor-Grip Technology for weed control in dicamba-tolerant (DT) crops have resulted in un-intended drifts, partly due to windy and common temperature inversions in many parts of United States. It is unclear if the dicamba-based herbicides made of different formulations or technologies have differential impact on sensitive soybeans including a conventional variety. Thus, field studies were conducted in 2016 and 2017 to evaluate the relative sensitivity of a conventional soybean to micro-rates of three dicambabased herbicide products (Clarity", Engenia and XtendiMax ${ }^{\circ}$ ) applied at second trifoliate (V2), seventh trifoliate/beginning of flowering (V7/R1), and full flowering (R2) stages of soybean. The dicamba micro-rates were $0,0.56,1.12,5.6,11.2$, and $56 \mathrm{~g}$ ae ha $^{-1}$; equivalent to $0,1 / 1000,1 / 500$, $1 / 100,1 / 50,1 / 10$ of the standard rate $\left(560 \mathrm{~g} \mathrm{ae} \mathrm{ha}^{-1}\right)$ respectively. The experimental design was a randomized complete block design in a split-split-plot arrangement with 4 replications. There was no significant difference in visual injury, growth or yield response of the conventional soybean to the three dicamba herbicides. The dicamba micro rates caused $40-80 \%$ visual injury and $0-97 \%$ yield loss depending on the growth stage of application. The estimated effective doses (ED values) suggested that conventional soybeans exposed to dicamba micro-rates at V7/R1 growth stage were more sensitive than those exposed at V2 and R2 growth stages. Based on the ED values, about $0.1 \%$ of dicamba standard rate was enough to cause $10 \%$ soybean yield loss when applied at V7/R1 stage; while about $1 \%$ of dicamba standard rate was required to cause the same level of yield loss when applied at V2 or R2 stage. By implication, dicamba drift on sensitive soybean plants should be avoided to prevent yield loss.

Key words: dicamba drift, dicamba formulation, injury, Clarity ${ }^{\circ}$ Engenia ${ }^{\circ}$ XtenidMax. 


\section{INTRODUCTION}

Soybeans are grown on about 36 million ha of land in United States, with yields toping close to 120 million tons in 2017 (USDA, 2018). However, increase use of dicamba-based herbicides in USA is a threat to soybean production. Dicamba is used for selective broadleaf weed control in grassy type crops (eg. corn, cereals) and recently in genetically modified dicamba-tolerant (DT) soybeans. Since sensitive crops such as conventional and organic soybeans are often grown adjacent to the DT soybeans, drift from dicamba application can occur and impair growth and lower yield of sensitive soybeans (Andersen et al., 2004; Robinson et al., 2013). However, the level of damage largely depend on the dicamba rate, time of exposure, and environment (Weidenhamer et al., 1989; Soltani et al., 2016).

It has been reported that soybean yield loss due to injuries by dicamba can range from 3 to $76 \%$, depending on the rate, growth stage of exposure and weather conditions (Andersen et al., 2004; Auch and Arnold, 1978; Soltani et al., 2016, Osipitan and Knezevic 2017). For example, dicamba rate of $60 \mathrm{~g}^{2} \mathrm{ha}^{-1}$ caused $20 \%$ soybean yield loss when applied at early vegetative stage (V2), while yield loss was $50 \%$ when applied at during early flowering stage (R1) (Soltani et al., 2016). In addition, studies have shown that weather condition, especially rainfall events soon after the drift occurrence is an important factor that determines level of soybean damage caused by dicamba (Weidenhamer et al., 1989; Robinson et al., 2013; Osipitan and Knezevic 2017). Weidenhamer et al. (1989) reported that 10\% yield reduction was caused by $0.4 \mathrm{~g}$ ae ha ${ }^{-1}$ of dicamba in a dry field condition compared to higher amount ( $\left.15 \mathrm{~g} \mathrm{ae} \mathrm{ha}^{-1}\right)$ of dicamba required in a field with adequate water. Similarly, Osipitan and Knezevic (2017) reported that $1.85 \mathrm{~g}_{\text {ae }} \mathrm{ha}^{-1}$ of dicamba caused 10 yield loss when applied at $\mathrm{V} 2$ growth stage in a dryland; while higher dose, $6.14 \mathrm{~g}_{\text {ae ha-1 }}$ of dicamba was required to cause the same level of yield loss in an irrigated land.

Exposure of soybean to dicamba usually occur from contamination of sprayer, physical drift, or volatilization. Reports have confirmed that even with careful application of dicamba under favorable weather conditions, a rightly applied dicamba can potentially move at least 3 days after application to an un-intended plant or field (WSSA, 2018).

The parent acid of dicamba (3,6-dichloro-2-methoxybenzoic acid) is relatively volatile with a vapor pressure of $4.5 \times 10^{-3} \mathrm{~Pa}$ at $25^{\circ} \mathrm{C}$ compared to other herbicides (WSSA, 2018). In the past, dicamba herbicides were primarily formulated as a salt to improve compatibility with hard water and other herbicides, with little or no difference in volatility compared to the unformulated parent acid (Hartzler, 2017). An example of early dicamba salt formulation was dimethylamine (e.g., Banvel"). Over the years, different formulations such as diglycolamine (e.g., Clarity $^{\circ}$ ) with relatively lower volatility were developed. Most recently, new dicamba herbicides such as XtendiMax (a diglycolamine) with Vapor-Grip technology and Engenia ${ }^{\circ}[(N, N-B i s-(3-$ aminopropyl) methylamine] were formulated to further reduce the volatility of the parent acid. These developments suggest dicamba volatility can be influenced by the formulation; however, it is unclear if a dicamba drift from these different formulations have differential impacts on sensitive crops such as conventional soybeans. Thus, a study was conducted to evaluate the 
relative sensitivity of a conventional soybean to micro-rates of three dicamba based herbicide products (Clarity", Engenia and XtendiMax ${ }^{\circ}$ ) applied at three soybean growth stages.

\section{MATERIALS AND METHODS}

Experimental site and design. Field studies were conducted in 2016 and 2017 at Haskell Agricultural Laboratory of the University of Nebraska-Lincoln in Concord, NE $\left(42.37^{\circ} \mathrm{N}\right.$, $\left.96.68^{\circ} \mathrm{W}\right)$. In 2016 , the soil texture of the location was silty clay loam with $2.2 \%$ organic matter and $5.7 \mathrm{pH}$. In 2017, the soil texture was silty loam with $3.2 \%$ organic matter and 5.3 $\mathrm{pH}$. Conventional soybean, Pioneer P25T01S was seeded at 365,100 seeds ha-1 in $76 \mathrm{~cm}$ rows on May 25 (2016) and June 4 (2017). Plot dimension was $8 \mathrm{~m}$ by $3 \mathrm{~m}$. No tillage was used on the fields, previously cultivated with corn. The total rainfall from May to September were 416 and $352 \mathrm{~mm}$ in 2016 and 2017 respectively, compared to 30-yr average of $450 \mathrm{~mm}$. The average daily air temperature from May to September were 16 and $19^{\circ} \mathrm{C}$ in 2016 and 2017 respectively, compared to $20^{\circ} \mathrm{C}$ of 30 -yr average.

The experimental design was a randomized complete block design in a split-split-plot arrangement with 4 replications. The main plot treatments were application timing (growth stage) at second trifoliate (V2), seventh trifoliate/beginning of flowering (V7/R1), and full flowering (R2) stages of soybean. The sub-plot treatments consisted of three dicamba herbicides, namely: Clarity (dicamba diglycolamine salt, $480 \mathrm{~g} \mathrm{l}^{-1}$; BASF Corporation, 26 Davis drive, Research Triangle Park, NC), Engenia (dicamba N,N-Bis-[3-aminopropyl] methylamine salt, $600 \mathrm{~g} \mathrm{l}^{-1}$; BASF Corporation, 26 Davis drive, Research Triangle Park, NC) and XtendiMax (dicamba diglycolamine salt, $350 \mathrm{~g} \mathrm{l}^{-1} ; 800$ North Lindbergh Blvd, St. Louis, MI). The sub-sub plot treatments consisted of dicamba rates of $0,0.56,1.12,5.6,11.2$, and $56 \mathrm{~g}$ ae ha-1; equivalent to $0,1 / 1000,1 / 500,1 / 100,1 / 50,1 / 10$ of the standard rate $(560 \mathrm{~g}$ ae $\mathrm{ha}^{-1}$ ) respectively. All dicamba treatments were applied with a spray volume of $140 \mathrm{~L} \mathrm{ha}^{-1}$ at $276 \mathrm{kPa}$ through four 11004-VP flat spray nozzles (Turbo TeeJet Induction, Spraying systems Co., P.O. Box 7900, Wheaton, IL 60187) on $200 \mathrm{~cm}$ wide boom of a $\mathrm{CO}_{2}$-pressurized backpack sprayer. Weather conditions at time of applications of treatments appears generally favorable as air temperatures were 18 to $20^{\circ} \mathrm{C}(2016)$ and 21 to $25^{\circ} \mathrm{C}(2017)$ while wind speeds were less than 6 to $9 \mathrm{~km} \mathrm{~h}^{-1}$ in both years.

Data collection. Visually rated percentage injuries of soybean on the scale of 0 to 100 were collected at 7, 14, 21 and 28 days after treatment (DAT); where 0 represents no injury, 100 represents dead plant. Plant height was collected at 7, 14, 21 and 28 DAT from of five arbitrarily selected soybean plants. Number of branches, days to canopy closure, number of flowering nodes, and days to physiological maturity of soybean plants was also documented. At maturity, 6 soybean plants were randomly selected from the two middle rows of each plot to determine yield components such as pods plant ${ }^{-1}$, seeds pod $^{-1}$, seeds $\mathrm{m}^{-2}$, and 100-seed weight. Soybean seeds were harvested from plants within the two middles rows using a Combine (Almaco SP40, Nevada, IA, USA); with seed yield adjusted for $130 \mathrm{~g} \mathrm{~kg}^{-1}$ moisture. 
Statistical analysis. There were no significant interactions between treatments and year of study on all data, therefore the data was pooled from both years for each treatment. Regression analysis was conducted using a four-parameter log-logistic model to describe the relationship between dicamba micro-rates, and various parameters (visual injury, plant height, days to physiological maturity, yield components loss, grain yield loss) at various growth stages using the procedure described by Knezevic et al. (2007). The effective doses (ED values) given a certain level of soybean response (e.g. 10, 20 and 50\% threshold) were used to determine the sensitivity of conventional soybean to the dicamba herbicides at different growth stages; the lower the required dose, the higher the sensitivity (Knezevic et al., 2018). The respective standard errors (SE) of the ED values were used to compare the different levels of each factor. The regression analyses were conducted using $\mathrm{R}$ version 3.4.1 (R Core Team, 2017).

\section{RESULTS AND DISCUSSION}

Crop injury. There was an increase in visual injury with increased dicamba micro-rate (Figure 1). The observed injuries were visible in the form of leaf cupping, curling and twisting of stem (epinasty), stunted shoot, swollen nodes and necrosis. Additional symptoms such as flower abortion, swollen nodes and curling pods were observed when dicamba was applied at V7/R1 or R2 stage. The leaf and stem injury appeared within 7 to 14 days after treatment (DAT) and persistence of injury depends on the dicamba micro-rate. For example, the soybeans treated at V2 stage with the highest rate (1/10 of the standard rate) had observable leaf injury throughout the growing season, while those treated with the lowest rate (1/1000 of the standard rate) had no observable leaf injury when plants were closed to physiological maturity. The injury caused by dicamba rates on the conventional soybean was not significantly different among the three tested products (Table 1). For example, the 1/10 of the standard rate of XtendiMax caused 73\% visual injury 21 DAT when applied at V2 growth stage, which was not significantly different from $74 \%$ injury caused by Clarity and Engenia (Table 1). Similar effects among the dicamba products were also observed when applied at V7/R1 and R2 stages. However, the greatest injury by these products was generally observed when applied at V7/R1 stage, with $1 / 10$ of the standard rate caused as much as $80 \%$ injury 21 DAT. A similar pattern of dicamba injury difference among growth stages was previously reported (Wax et al., 1969; Auch and Arnold, 1978; Robinson et al., 2013). Contrarily, Griffin et al., (2013) reported that soybean treated with dicamba at early vegetative (V3) stage had $14 \%$ greater injury than application at R1 stage; though, they further reported that damage caused on shoot growth suggested otherwise.

Based on ED values, the conventional soybean injury had equal sensitivity to the dicamba products; however, the plants are generally most sensitive to dicamba applied at V7/R1 stage (Table 1). For example, Clarity dose of $0.06 \mathrm{~g}^{\circ} \mathrm{ha}^{-1}\left(\mathrm{ED}_{20}\right)$ caused $20 \%$ injury when applied at V7/R1 stage; whereas a higher dose of $0.36 \mathrm{~g}$ ae ha-1 or $0.26 \mathrm{~g} \mathrm{ae} \mathrm{ha}^{-1}$ of Clarity" was needed for the same level of injury when applied at V2 or R2 stage respectively. Similarly, Clarity dose of 
Table 1. Parameter estimates and dose of dicamba products that resulted in $10 \%\left(\mathrm{ED}_{10}\right), 20 \%\left(\mathrm{ED}_{20}\right)$, and $50 \%$ $\left(\mathrm{ED}_{50}\right)$ injury in conventional soybean sprayed at three growth stages. Parameter $\mathrm{B}, \mathrm{C}$, and $\mathrm{D}$ represent slope, lower limit, and upper limit, respectively.

Tabela 1. Procena parametara i doze herbicida na bazi dikambe koja je rezultovala u $10 \%\left(\mathrm{ED}_{10}\right), 20 \%\left(\mathrm{ED}_{20}\right) \mathrm{i}$ $50 \%\left(\mathrm{ED}_{50}\right)$ oštećenjima konvencionalnih sorti soje, tretiranih u tri faze razvoja. Parametri $\mathrm{B}, \mathrm{C}$ i D predstavljaju nagib krive, donju granicu i gornju granicu, redom.

\begin{tabular}{llllllll}
\hline Dicamba & Growth stage & B (SE) a & C (SE) & D (SE) & ED10 (SE) & ED20 (SE) & ED50 (SE) \\
\hline \multirow{2}{*}{ Clarity $^{\infty}$} & V2 & $-0.68(0.27)$ & $0.07(0.01)$ & $74(3.92)$ & $0.15(0.04)$ & $0.36(0.11)$ & $0.88(0.13)$ \\
& V7/R1 & $-0.91(0.13)$ & $0.13(0.09)$ & $80(1.38)$ & $0.02(0.03)$ & $0.06(0.01)$ & $0.30(0.02)$ \\
& R2 & $-0.48(0.07)$ & $0.06(0.9)$ & $70(3.14)$ & $0.11(0.00)$ & $0.26(0.01)$ & $0.94(0.12)$ \\
\hline Engenia $^{\infty}$ & V2 & $-0.77(0.12)$ & $0.07(0.03)$ & $74(3.31)$ & $0.13(0.04)$ & $0.20(0.06)$ & $0.62(0.09)$ \\
& V7/R1 & $-0.71(0.09)$ & $0.08(0.03)$ & $79(1.08)$ & $0.06(0.00)$ & $0.07(0.01)$ & $0.41(0.03)$ \\
& R2 & $-0.57(0.04)$ & $0.09(0.01)$ & $68(3.16)$ & $0.10(0.00)$ & $0.18(0.01)$ & $1.04(0.22)$ \\
\hline XtendiMax $^{\infty}$ & V2 & $-1.38(0.31)$ & $0.08(0.3)$ & $73(4.02)$ & $0.03(0.01)$ & $0.24(0.02)$ & $0.62(0.07)$ \\
& V7/R1 & $-0.61(0.05)$ & $0.07(0.04)$ & $79(1.01)$ & $0.01(0.01)$ & $0.08(0.02)$ & $0.33(0.07)$ \\
& R2 & $-0.49(0.09)$ & $0.00(0.00)$ & $68(1.04)$ & $0.07(0.00)$ & $0.49(0.02)$ & $1.02(0.81)$ \\
\hline
\end{tabular}

a Estimates were compared using standard errors (SE).
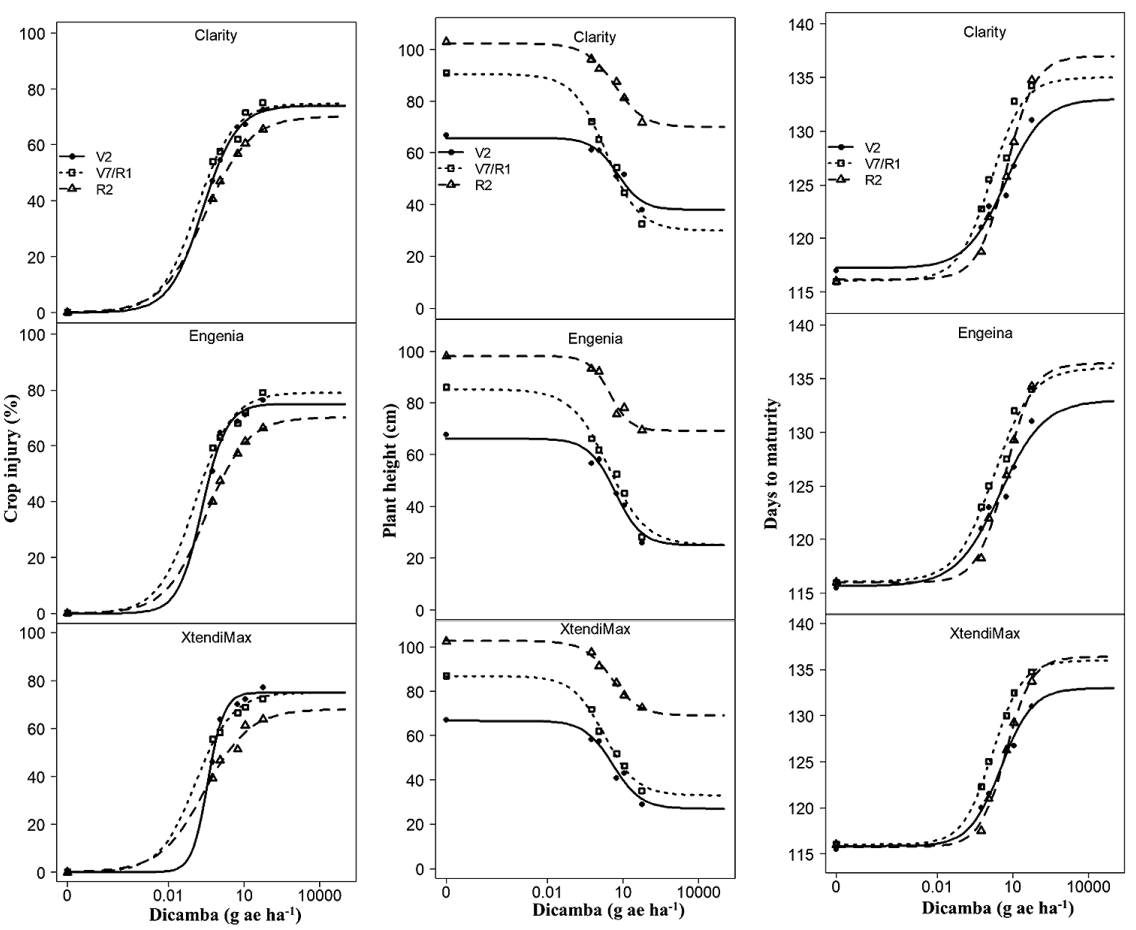

Figure 1. Soybean injury, plant height reduction and physiological maturity delay caused by increasing micro rates of dicamba products at different growth stages of application.

Grafik 1. Oštećenja soje, redukcija visine biljaka i kašnjenje fiziološke zrelosti izazvane povećanim mikrodozama herbicida na bazi dikambe u različitim fazama primene. 
$0.30 \mathrm{~g} \mathrm{ae} \mathrm{ha}^{-1}\left(\mathrm{ED}_{50}\right)$ caused $50 \%$ injury when at V7/R1 stage, compared to higher dose of 0.88 g ae ha-1 or $0.94 \mathrm{~g}$ ae ha-1 required for $50 \%$ injury when applied at V2 or R2 stage respectively. The ED values of Engenia " and XtendiMax ${ }^{\star}$ were generally similar to those reported for Clarity at all growth stages. In a study in which diglycolamine salt formulation (Clarity ${ }^{\circ}$ ) alone was evaluated, Robinson et al (2013) estimated that $4.55 \mathrm{~g} \mathrm{ae} \mathrm{ha}^{-1}$ of dicamba was required to cause $50 \%$ injury at V2 stage, compared to lower dose of $1.44 \mathrm{~g}^{-1 e} \mathrm{ha}^{-1}$ at V5 stage; suggesting that sensitivity of soybean to dicamba is influenced by growth stage of application.

Plant height reduction. Average height (28 DAT) of the nontreated conventional soybean plants was 65, 90 and $110 \mathrm{~cm}$ respectively at V2, V7/R1, and R2 stage of application. Increasing rates of dicamba significantly reduced plant height (Figure 1). The reduction in plant height was similar among the dicamba products (Table 2). For example, the highest Clarity rate (1/10 of the standard rate) reduced plant height by 39,67 , and $27 \%$ at 28 DAT, when applied V2, V7/R1 and R2 growth stage respectively; and these were similar to plant height reduction of about 37, 64 and 29\% observed 28 DAT with the application of Engenia or XtendiMax at V2, V7/R1 and R2 growth stage of application, respectively. Similarly, Griffin et al. (2013) reported 39\% reduction in soybean plant height with $1 / 10$ standard rate of Clarity applied at V2, compared to $46 \%$ height reduction of the same rate when applied at R1.

According to the ED values, of the three growth stages, the conventional soybean plant height was most sensitive to the dicamba products when applied at V7/R1 stage (Table 2). For example, a dose range of 0.57 to $0.64 \mathrm{~g}$ ae ha-1 of dicamba $\left(\mathrm{ED}_{10}\right)$ applied at V2 stage

Table 2. Dose of dicamba products that resulted in $10 \%\left(\mathrm{ED}_{10}\right)$, and $50 \%\left(\mathrm{ED}_{50}\right)$ plant height reduction and physiological maturity delay of conventional soybean applied at three growth stages.

Tabela 2. Doze herbicida na bazi dikambe koje rezultuju $10 \%\left(\mathrm{ED}_{10}\right)$ i $50 \%\left(\mathrm{ED}_{50}\right)$ redukcijom visine i kašnjenjem fiziološke zrelosti konvencionalnih sorti soje, tretiranih u tri faze razvoja.

\begin{tabular}{|c|c|c|c|c|c|}
\hline \multirow[b]{2}{*}{ Dicamba } & \multirow[b]{2}{*}{ Growth stage } & \multicolumn{2}{|c|}{ Plant height } & \multicolumn{2}{|c|}{ Maturity } \\
\hline & & $\mathrm{ED}_{10}(\mathrm{SE})^{\mathrm{a}}$ & $\mathrm{ED}_{50}(\mathrm{SE})$ & $\mathrm{ED}_{10}(\mathrm{SE})$ & $\mathrm{ED}_{50}(\mathrm{SE})$ \\
\hline \multirow[t]{3}{*}{ Clarity $^{\circledast}$} & $\mathrm{V} 2$ & $0.59(0.20)$ & $7.92(1.34)$ & $0.38(0.09)$ & $3.29(0.19)$ \\
\hline & $\mathrm{V} 7 / \mathrm{R} 1$ & $0.26(0.09)$ & $4.41(0.23)$ & $0.19(0.03)$ & $1.09(0.11)$ \\
\hline & $\mathrm{R} 2$ & $0.79(0.21)$ & $11.1(1.95)$ & $0.44(0.07)$ & $3.02(0.26)$ \\
\hline \multirow[t]{3}{*}{ Engenia $^{\circledR}$} & V2 & $0.64(0.02)$ & $7.27(1.83)$ & $0.31(0.06)$ & $2.98(0.14)$ \\
\hline & V7/R1 & $0.24(0.10)$ & $4.21(0.74)$ & $0.12(0.04)$ & $0.61(0.09)$ \\
\hline & $\mathrm{R} 2$ & $1.07(0.86)$ & $9.88(2.27)$ & $0.42(0.11)$ & $2.94(0.44)$ \\
\hline \multirow[t]{3}{*}{ XtendiMax ${ }^{\circledast}$} & $\mathrm{V} 2$ & $0.57(0.21)$ & $8.04(3.12)$ & $0.37(0.06)$ & $2.96(0.14)$ \\
\hline & V7/R1 & $0.22(0.07)$ & $3.72(1.04)$ & $0.12(0.02)$ & $0.54(0.17)$ \\
\hline & $\mathrm{R} 2$ & $1.19(0.23)$ & $11.6(1.22)$ & $0.38(0.19)$ & $2.71(0.12)$ \\
\hline
\end{tabular}

a Estimates were compared using standard errors (SE). 
was required to cause $10 \%(\sim 7 \mathrm{~cm})$ reduction in plant height across all three products at 28 DAT; compared to a significantly lower dose of 0.22 to $0.24 \mathrm{~g}$ ae ha-1 required for $10 \%$ height reduction at the V7/R1 stage across all three products 28 DAT (Table 2). In addition, based on $\mathrm{ED}_{50}$, a dose range of 7.27 to $8.04 \mathrm{~g}$ ae ha- $\mathrm{h}^{-1}$ applied at V2 stage caused $50 \%(\sim 32 \mathrm{~cm})$ reduction in plant height $28 \mathrm{DAT}$ across all three products, whereas a significantly lower dose of 3.72 to $4.41 \mathrm{~g}$ ae ha ${ }^{-1}$ caused $50 \%$ height reduction for the V7/R1 stage (Table 2). There was no significant difference in plant height sensitivity to the dicamba doses between V2 stage soybean and R2 stage soybean except with application of XtendiMax . An XtendiMax dose of $7.92 \mathrm{~g} \mathrm{ae} \mathrm{ha}^{-1}\left(\mathrm{ED}_{50}\right)$ was required to cause $50 \%$ reduction in plant height of $\mathrm{V} 2$ stage soybean, compared to a significantly higher XtendiMax dose of $11.2 \mathrm{~g}^{\circ}$ ae ha-1 required for the same level height reduction of R2 stage soybean. The difference between sensitivity of V2 and R2 stage soybeans to dicamba was consistent with $\mathrm{ED}_{10}$ estimates for XtendiMax ${ }^{\circ}$. Similar to our results with Clarity and Engenia', a previous study showed no significant difference in ED values for plant height reduction between V2 and R2 dicamba treated soybeans when Clarity was used (Robinson et al., 2013).

The reduction in plant height caused by dicamba could be potential tool to quickly predict yield loss (Weidenhamer et al., 1989; Kelley et al., 2005; Robinson et al., 2013). Wax et al. (1969) reported that a dicamba dose of $17.5 \mathrm{~g} \mathrm{ha}^{-1}$ applied at R1 stage caused $46 \%$ soybean plant height reduction with associated yield reduction of 52\%; while Griffin et al. (2013) reported that the same rate caused $28 \%$ reduction in plant height which was followed by $36 \%$ yield reduction. Weidenhamer et al. (1989) reported that $16 \mathrm{~g} \mathrm{ha}^{-1}$ of dicamba applied at midbloom reduced plant height by $25 \%$ with subsequent soybean yield reduction of about $23 \%$. The quantitative relationship between soybean height and yield loss varied widely among previous studies; thus, height could be more reliable as a qualitative than being quantitative predictor of yield loss (Weidenhamer et al., 1989). In addition, a reduction in plant height may reduce photosynthesis that will result in reduced leaf area, fewer main-stem nodes, and delayed canopy closure, which could cause yield loss.

Delayed physiological maturity. Nontreated conventional soybean attained physiological maturity 116 days after emergence. Physiological maturity was delayed with increase in dicamba rates (Figure 1). All three dicamba products delayed the physiological maturity of treated soybeans in a similar extent. For example, the highest rate of Clarity (1/10 of the standard rate) caused 19, 26 and 23 days delay in physiological maturity of the conventional soybean when applied at V2, V7/R1, and R2 growth stages, respectively. However, a similar pattern of maturity delay by Clarity was observed with the application of Engenia or XtendiMax". The soybean physiological maturity was most sensitive to dicamba when applied at V7/R1 stage. For example, a significantly lower XtendiMax dose of $0.54 \mathrm{~g}^{\circ}$ ae ha-1 applied at V7/R1 stage compared to higher doses of $2.96 \mathrm{~g}$ ae ha-1 (for V2) or $2.71 \mathrm{~g}^{-1 e} \mathrm{ha}^{-1}$ (for R2) was required to cause $50 \%$ delay in physiological maturity. The estimated doses of the three herbicides that caused the same level of maturity delay were not significantly different. An implication of the delayed soybean maturity is a delayed harvest time, which can make soybean subject to early frost. 
Soybean yields. The average seed yield of the conventional soybeans unexposed to dicamba was $4050 \mathrm{~kg} \mathrm{ha}^{-1}$. Yields were significantly affected by the application of any of the three dicamba products irrespective of the growth stage of application. However, yields were more severely affected when the conventional soybeans were treated with dicamba at V7/R1 stage compared to the two other stages (V2 and R2). For instance, application of 1/10 of Clarity" label rate at V7/R1 soybean stage resulted in an extremely low yield of $150 \mathrm{~kg} \mathrm{ha}^{-1}$ compared to $1350 \mathrm{~kg} \mathrm{ha}^{-1}$ yield when applied at R2 stage or $2100 \mathrm{~kg}$ when applied at V2 stage. Similar to Clarity', a yield of 210, 1309 and $2001 \mathrm{~kg} \mathrm{ha}^{-1}$ was obtained at V7/R1, R2 and V2 stage respectively when soybeans were treated with Engenia at $1 / 10$ of standard rate; and these yields were not different in XtendiMax treated soybeans (Figure 2, Table 3). Similarly, Griffin et al. (2013) reported that soybean with no dicamba application yielded $3400 \mathrm{~kg} \mathrm{ha}^{-1}$, application of Clarity at $1 / 10$ of the standard rate reduced yield to $1300 \mathrm{~kg} \mathrm{ha}^{-1}$ when applied at V3 stage, with further reduction to $900 \mathrm{~kg} \mathrm{ha}^{-1}$ when applied at R1 stage.

Soybean yield components. The dicamba products negatively affected the yield components irrespective of growth stage of application (Figure 2, Table 4). The affected yield components were pods plant ${ }^{-1}$, seeds pod $^{-1}$ and 100 -seed weight. In addition, the estimated ED values indicated that yield components of soybean treated with dicamba at V7/R1 stage was the most sensitive compared the soybean treated at V2 and R2 stages.
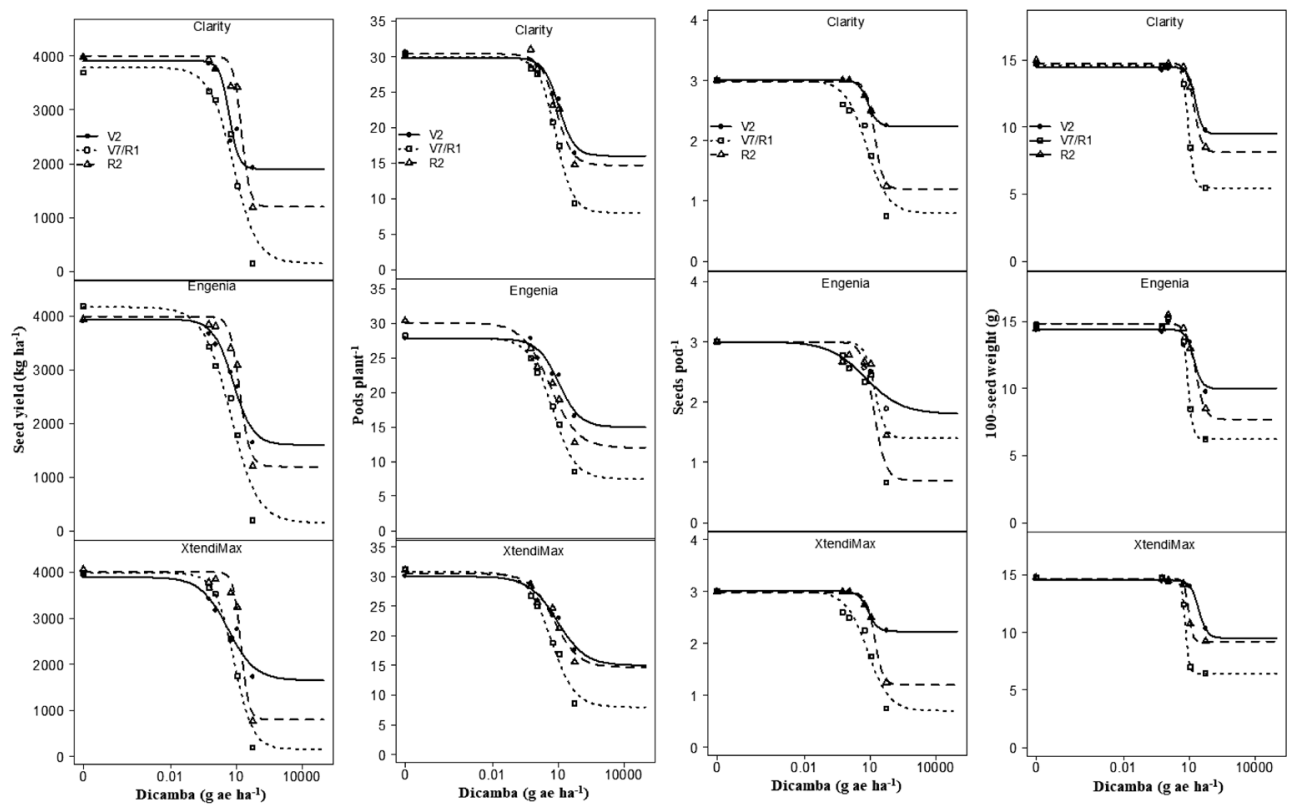

Figure 2. Soybean yield and yield components as influenced by increasing micro - rates of dicamba products at different growth stages of application.

Grafik 2. Prinos soje i prinos komponenti usled povećanja mikrodoza herbicida na bazi dikambe u različitim fazaman primene. 
Table 3. Parameter estimates and dose of dicamba products that resulted in $5 \%\left(\mathrm{ED}_{5}\right), 10 \%\left(\mathrm{ED}_{10}\right)$, and $20 \%\left(\mathrm{ED}_{20}\right)$ yield loss of conventional soybean sprayed at three growth stages. Parameter B, C, D and $\mathrm{I}_{50}$ represent slope, lower limit, upper limit and dose at inflection point respectively.

Tabela 3. Procene parametara i doze herbicida na bazi dikambe koji rezultuju u 5\% $\left(\mathrm{ED}_{5}\right), 10 \%\left(\mathrm{ED}_{10}\right)$ i $20 \%\left(\mathrm{ED}_{20}\right)$ gubitku prinosa konvencionalnih sorti soje tretiranih u tri razvojne faze. Parametri B, C, D i $\mathrm{I}_{50}$ predstavljaju nagib krive, donju granicu, gornju granicu i dozu na tački preloma, redom.

\begin{tabular}{lcccccccc}
\hline Dicamba & Growth stage & $\mathbf{B}(\mathrm{SE})^{\mathbf{a}}$ & $\mathbf{C}(\mathrm{SE})$ & $\mathbf{D}(\mathrm{SE})$ & $\mathbf{I}_{\mathbf{5 0}}(\mathrm{SE})$ & $\mathbf{E D}_{\mathbf{5}}(\mathrm{SE})$ & $\mathbf{E D}_{\mathbf{1 0}}(\mathrm{SE})$ & $\mathrm{ED}_{\mathbf{2 0}}(\mathrm{SE})$ \\
\hline Clarity $^{\circ}$ & $\mathrm{V} 2$ & $3.01(0.72)$ & $2100(102)$ & $3920(233)$ & $12.0(1.44)$ & $1.61(0.40)$ & $4.14(0.80)$ & $7.10(0.42)$ \\
& $\mathrm{V} 7 / \mathrm{R} 1$ & $2.40(0.61)$ & $150(44)$ & $3890(197)$ & $6.09(0.36)$ & $0.31(0.13)$ & $0.37(0.14)$ & $1.09(0.09)$ \\
& $\mathrm{R} 2$ & $2.31(0.32)$ & $1350(136)$ & $4020(301)$ & $10.1(2.43)$ & $1.07(0.22)$ & $3.36(0.35)$ & $5.19(0.34)$ \\
\hline Engenia & $\mathrm{V} 2$ & $2.11(1.02)$ & $2001(108)$ & $4002(179)$ & $13.1(2.38)$ & $1.81(0.20)$ & $4.11(0.10)$ & $7.11(0.26)$ \\
& $\mathrm{V} 7 / \mathrm{R} 1$ & $3.30(0.94)$ & $210(24)$ & $4210(149)$ & $5.33(1.05)$ & $0.16(0.40)$ & $0.56(0.16)$ & $1.23(0.12)$ \\
& $\mathrm{R} 2$ & $1.34(1.20)$ & $1309(86)$ & $4050(205)$ & $11.2(1.01)$ & $1.13(0.19)$ & $4.01(0.43)$ & $6.02(0.21)$ \\
\hline XtendiMax & $\mathrm{V} 2$ & $2.09(0.82)$ & $2005(306)$ & $3950(301)$ & $10.9(2.11)$ & $1.65(0.01)$ & $4.21(0.15)$ & $5.23(0.12)$ \\
& $\mathrm{V} 7 / \mathrm{R} 1$ & $2.05(0.80)$ & $129(61)$ & $4015(381)$ & $4.32(1.05)$ & $0.23(0.15)$ & $0.48(0.27)$ & $1.12(0.23)$ \\
& $\mathrm{R} 2$ & $1.92(0.90)$ & $1009(185)$ & $4020(402)$ & $13.2(2.21)$ & $2.57(0.22)$ & $3.97(0.26)$ & $6.13(1.24)$ \\
\hline
\end{tabular}

a Estimates were compared using standard errors (SE).

Table 4. Dicamba dose that caused $5 \%\left(\mathrm{ED}_{5}\right)$ and $10 \%\left(\mathrm{ED}_{10}\right)$ reduction in pods plant ${ }^{-1}$, seeds pod ${ }^{-1}$, 100 - seed weight reduction of conventional soybean sprayed at three stages.

Tabela 4. Doze dikambe koje su uzrokovale 5\% $\left(\mathrm{ED}_{5}\right)$ i $10 \%\left(\mathrm{ED}_{10}\right)$ redukciju u boju mahuna po biljci, semena po biljci i redukciji težine 100 semena kod konvencionalnih sorti soje tretiranih u tri faze razvoja.

\begin{tabular}{|c|c|c|c|c|c|c|c|}
\hline \multirow[b]{2}{*}{ Dicamba } & \multirow[b]{2}{*}{ Growth stage } & \multicolumn{2}{|c|}{ Pods plant ${ }^{-1}$} & \multicolumn{2}{|c|}{ Seeds pod-1 } & \multicolumn{2}{|c|}{ 100-seed weight } \\
\hline & & $\mathrm{ED}_{5}(\mathrm{SE})^{\mathrm{a}}$ & $\mathrm{ED}_{10}(\mathrm{SE})$ & $\mathrm{ED}_{5}(\mathrm{SE})$ & $\mathrm{ED}_{10}(\mathrm{SE})$ & $\mathrm{ED}_{5}(\mathrm{SE})$ & $\mathrm{ED}_{10}(\mathrm{SE})$ \\
\hline & & & - -------- & -g & $\mathrm{ha}^{-1}-\ldots$ & & \\
\hline \multirow[t]{3}{*}{ Clarity } & $\mathrm{V} 2$ & $1.71(0.02)$ & $7.53(1.83)$ & $5.09(0.06)$ & $6.19(1.35)$ & $2.13(0.11)$ & $4.74(0.28)$ \\
\hline & $\mathrm{V} 7 / \mathrm{R} 1$ & $0.65(1.20)$ & $2.11(0.74)$ & $2.09(1.02)$ & $3.69(0.09)$ & $0.88(0.13)$ & $2.01(0.54)$ \\
\hline & $\mathrm{R} 2$ & $1.88(0.36)$ & $6.78(2.27)$ & $5.14(0.51)$ & $5.96(0.44)$ & $2.67(0.21)$ & $5.06(0.98)$ \\
\hline \multirow[t]{3}{*}{ Engenia } & $\mathrm{V} 2$ & $2.02(1.91)$ & $7.03(3.22)$ & $5.12(0.26)$ & $6.11(0.12)$ & $3.18(1.90)$ & $5.49(1.01)$ \\
\hline & V7/R1 & $1.02(1.17)$ & $3.62(1.74)$ & $1.99(0.01)$ & $3.92(0.17)$ & $1.21(0.01)$ & $2.78(0.98)$ \\
\hline & $\mathrm{R} 2$ & $2.28(1.13)$ & $7.06(1.42)$ & $4.99(0.29)$ & $6.01(0.52)$ & $3.02(0.98)$ & $5.09(1.01)$ \\
\hline \multirow[t]{3}{*}{ XtendiMax } & $\mathrm{V} 2$ & $1.86(0.20)$ & $6.22(1.24)$ & $4.92(0.19)$ & $6.16(0.49)$ & $2.67(0.92)$ & $4.39(0.35)$ \\
\hline & $\mathrm{V} 7 / \mathrm{R} 1$ & $0.67(0.29)$ & $2.11(0.83)$ & $1.09(0.13)$ & $2.00(0.51)$ & $0.96(0.32)$ & $1.01(0.32)$ \\
\hline & $\mathrm{R} 2$ & $1.54(0.90)$ & $5.19(2.05)$ & $4.29(0.37)$ & $6.12(0.26)$ & $2.08(0.38)$ & $4.22(1.19)$ \\
\hline
\end{tabular}

a Estimates were compared using standard errors (SE).

Pods per plant. The nontreated conventional soybean produced about 31 pods plant $^{-1}$, however, the pods were significantly reduced depending on the dicamba rate and growth stage of application. For example, application of 1/10 of the Engenia ${ }^{\circ}$ standard rate at V2, V7/R1 or R2 stage reduced pods to 15,11 or 9 plant $^{-1}$ respectively. The ED values suggested that pods 
plant $^{-1}$ was most sensitive to the dicamba products when applied at V7/R1 stage. For example, XtendiMax dose of $0.67 \mathrm{~g}^{\circ}$ ae ha$^{-1}\left(\mathrm{ED}_{10}\right)$ was required to cause $10 \%$ reduction in pod plant ${ }^{-1}$, compared to higher dose of 5.19 to $6.22 \mathrm{~g}$ ae ha-1 required when applied at V2 or R2 stage.

Seeds per pod. The dicamba products applied at $1 / 10$ of the standard rate reduced 3 seeds pod $^{-1}$ obtained in nontreated soybeans to about 1 seed $^{\text {pod }}{ }^{-1}$ when applied at V7/R1 stage, or to 2 seeds pod $^{-1}$ when applied at R2 stage. Based on the ED values, seeds pod ${ }^{-1}$ was reduced $10 \%$ with 6.11 to $6.19 \mathrm{~g}^{2}$ ha ${ }^{-1}$ of the dicamba products when applied at V2 stage, whereas, 3.69 to $3.92 \mathrm{~g}$ ae ha-1 $^{-1}$ of the dicamba products caused the same level of reduction.

Seed weight. Seed weight was significantly reduced with increased dicamba micro-rates (Figure 2; Table 4). For example, with 1/10 of standard rate of the dicamba product, 100-seed weight was significantly reduced to 11,5 or $8 \mathrm{~g}$ in V2, V7/R1 or R2 stage dicamba treated soybeans respectively; compared to $15 \mathrm{~g}$ of 100 -seed weight in a nontreated soybean. According to ED values, seed weight was reduced $10 \%$ with $1.97 \mathrm{~g}^{\mathrm{ge} \mathrm{ha}} \mathrm{h}^{-1}$ of XtendiMax when applied at V7/R1 compared to 4.03 and $4.13 \mathrm{~g}$ ae ha-1 for V2 and R2 stage respectively; and similar results were obtained with the use of other products (Clarity ${ }^{\circ}$ and Engenia ${ }^{\circ}$ ). A similar impact of dicamba on soybean yield components such as such as pod plant ${ }^{-1}$, seeds pod ${ }^{-1}$, seed weight and reproductive nodes have previously been reported to be negatively affected by auxin herbicides (Kelley et al., 2005; Robinson et al., 2013; Soltani et al., 2016).

Soybean yield loss. Yield loss generally increased with increased dicamba micro-rates of each product (Figure 3). Yield loss caused by the dicamba products was not significantly different. For example, Clarity treated soybeans at V2 stage with 1/10 of the standard rate resulted in 50\% yield loss, which was not significantly different from 52\% and 51\% yield loss in Engenia and XtendiMax treated soybeans, respectively (Figure 3, Table 3). Similarly, Soltani et al. (2016) reported $45 \%$ yield loss with $1 / 10$ of dicamba standard rate when applied at V2 stage. Of the three stages, the yields of conventional soybeans treated with the dicamba products at V7/R1 stage was the most reduced. For example, Clarity treated soybeans at V7/ R1 stage with $1 / 10$ of the standard rate caused about $96 \%$ yield loss, which was similar to $97 \%$ yield reduction in Engenia and XtendiMax treated soybeans. The lowest dicamba rate $(1 / 1000$ of the standard rate) used in this study, caused about $20 \%$ yield loss when applied at V7/R1 stage with all products, compared to no yield loss when applied at V2 or R2. This rate was shown to correspond to vapor drift exposure (Egan and Mortensen, 2012).

In addition, the estimated ED values indicated that yield of soybean treated with dicamba at V7/R1 stage was the most sensitive compared to soybean treated at V2 and R2 stages. The estimated Engenia ${ }^{\circ}$ dose of $4.11 \mathrm{~g}$ ae ha-1 $\left(\mathrm{ED}_{10}\right)$ caused $10 \%$ yield loss when applied at V2 stage, whereas at V7/R1 stage of application, Engenia ${ }^{\circ}$ dose of $0.56 \mathrm{~g}^{2} \mathrm{e} \mathrm{ha}^{-1}$ caused the same level of yield loss. Similar to Engenia ${ }^{\circ}$, an XtendiMax dose of 4.21 and $0.48 \mathrm{~g}^{\circ}$ ae ha-1 was estimated for V2 and V7/R1 respectively. Those doses were generally similar to the estimates for Clarity". There was no difference in the estimated dose of dicamba required to cause $10 \%$ yield loss when applied at V2 and R2 soybean growth stages. The results were similar to those of Kelley et al. (2005) and Robinson et al. (2013) in which there no differential effective doses of dicamba for equal level of yield loss between V2 and R2 stage soybeans. 
In general, in our study, there was no difference in sensitivity of the conventional soybean to the three tested dicamba products irrespective of their formulation type and/or technology. The dicamba micro-rate and the growth stage at which the soybean plant was exposed to dicamba determined the level of yield loss. Important indicators of yield loss were visual injury, plant height reduction, and maturity delay that were caused by dicamba. Although there was high visual injury with apical meristem damage in plants exposed to dicamba at early vegetative (V2) stage, however, yield loss was reduced compared to early flowering (V7/R1) stage. The damaged apical meristem at V2 stage was compensated with increased branching, thereby increasing the number of reproductive nodes to reduce yield loss. In addition, early exposed soybean plants were able to recover overtime particularly, when exposed to low rates $\leq 1 / 1000$ of the standard rate. The high yield loss in plants exposed to dicamba at V7/R1 stage was due to increased flower abortion and plant height reduction that caused a reduced number of reproductive nodes. In summary, the dicamba rates used in this study corresponds to amounts of drift that could occur after field application of dicamba (Maybank et al., 1978; Derksen, 1989; Wolf et al., 1993; Egan and Mortensen, 2012), and a particle drift of 10\% (i.e., 1/10 of the standard rate) could cause as much as $97 \%$ yield loss depending on the growth stage of exposure. Thus, efforts must be made to avoid drift on sensitive soybeans irrespective of the dicamba herbicide or formulation.

\section{ACKNOWLEDGMENT}

This study was funded by Nebraska Soybean Board.

\section{REFERENCES}

Andersen, S. M., Clay, S. A., Wrage, L. J., Matthees, D.: Soybean foliage residues of dicamba and 2,4-D and correlation to application rates and yield. Agronomy Journal, 96 (3): 750 - 760, 2004.

Auch, D. E., Arnold, W.: Dicamba use and injury on soybeans ( Glycine max ) in South Dakota. Weed Science, 26 (5): $471-475,1978$.

Derksen, D. A.: Dicamba, chlorsulfuron and clopyralid as sprayer contaminants on sunflower (Helianthus annuus), mustard (Brassica juncea), and lentil (Lens culinaris), respectively. Weed Science, 37: 616 - 621, 1989.

Egan, J. F., Mortensen, D. A.: Quantifying vapor drift of dicamba herbicides applied to soybean. Environmental Toxicology and Chemistry, 31 (5): 1023 - 1031, 2012.

Griffin, J. L., Bauerle, M. J., Stephenson, D. O., Miller, D. K., Boudreaux, J. M.: Soybean response to dicamba applied at vegetative and reproductive growth stages. Weed Technology, 27 (4): 696 - 703, 2013.

Knezevic, S. Z., Osipitan, O. A., Scott, J. E.: Sensitivity of grape and tomato to micro - rates of dicamba - based herbicides. The Horticulture Journal, 5: 1 - 5, 2018.

Knezevic, S. Z., Streibig, J. C.Ritz, C.: Utilizing R software package for dose - response studies: The concept and data analysis. Weed Technology, 21 (3): 840 - 848, 2007.

Maybank, J., Yoshida, K., Grover, R.: Spray drift from agricultural pesticide applications. Journal of the Air Pollution Control Association, 28 (10): 1009 - 1014, 1978. 
Osipitan, O. A., Knezevic, S. Z.: Yield of dryland glyphosate-tolerant, glufosinate-tolerant, and conventional soybeans as influenced by micro-rates of clarity. $72^{\text {nd }}$ Annual Meeting of North Central Weed Science Society, ST. Louis, Mo, USA, abstract 106, 4 Dec, 2017.

Robinson, A. P., Simpson, D. M., Johnson, W. G.: Response of glyphosate - tolerant soybean yield components to dicamba exposure. Weed Science, 61 (4): 526 - 536, 2013.

Soltani, N., Nurse, R. E., Sikkema, P. H.: Response of glyphosate - resistant soybean to dicamba spray tank contamination during vegetative and reproductive growth stages. Canadian Journal of Plant Science, 96 (1): 160 - 164, 2016.

Weidenhamer, J., Jr, G. T.: Dicamba injury to soybean. Agronomy Journal, 643 (141): 637 - 643, 1989.

Wolf, T. M., Groverl, R., Wallace, I., Shewchuk, S. R., Maybanks, J.: Effect of protective shields on drift and deposition characteristics of field sprayers. Canadian Journal of Plant Science, 73: 26 - 273, 1993.

Weed Science Society of America (WSSA): WSSA research workshop for managing dicamba off - target movement: Final report, 2018.

www.wssa.net

\section{Relativna osetljivost konvencionalne soje u zavisnosti od fenofaze razvoja na tri različita herbicida na bazi dikambe}

\section{REZIME}

Široka upotreba herbicida na bazi dikame kao što su Clarity ${ }^{\oplus}$ (dikamba diglikolamin so, $480 \mathrm{~g}$ $\mathrm{l}^{-1}$ ), Engenia ${ }^{\oplus}$ (dikamba N,N-Bis-[3-aminopropil] metilamin so, $600 \mathrm{gl}^{-1}$ ) i XtendiMax ${ }^{\oplus}$ (dikamba diglikolamin so, $350 \mathrm{gl}^{-1}$ ) sa Vapor-Grip tehnologijom za suzbijanje korova u usevima tolerantnim na dikambu (DT) dovodi do nenamernih zanošenja, zbog vetra i uobičajenih temperaturnih inverzija u mnogim delovima Sjedinjenih Američkih Država. Nejasno je da li herbicidi na bazi dikambe, napravljeni u vidu različitih formulacija ili primenom različitih tehnologija različito utiču na osetljivu soju, uključujući i konvencionalne sorte. Stoga su 2016. i 2017. godine postavljeni poljski ogledi kako bi se procenila relativna osetljivost konvencionalne soje na smanjene količine primene tri herbicidna proizvoda na bazi dikambe $\left(\right.$ Clarity $^{\oplus}$, Engenia ${ }^{\oplus}$ i XtendiMax ${ }^{\circledast}$ ) primenjena u fazi druge troliske (V2), sedme troliske/početka cvetanja (V7/R1) i fazi punog cvetanja (R2) soje. Smanjene količine dikambe bile su: 0, 0,56, 1,12, 5,6, 11,2 i 56 g a.s. ha-1 ${ }^{-1}$ što je ekvivalentno $0,1 / 1000,1 / 500,1 / 100,1 / 50,1 / 10$ preporučene količine (560 g a.s. ha-1), redom. Eksperiment je postavljen po split-split-plot planu, u četiri ponavljanja, sa rasporedom tretmana po slučajnom blok sistemu. Nisu utvrđene razlike u vizuelnoj oceni, rastu i ostvarenom prinosu konvencionalne soje između tri različita herbicida na bazi dikambe. Smanjene količine dikambe uzrokovale su 40 $80 \%$ oštećenja biljaka i gubitak prinosa od 0-97\% u zavisnosti od faze rasta pri primeni herbicida. Procenjene efektivne doze (ED vrednosti) pokazale su da je konvencionalna soja bila osetljivija na primenu smanjenih količina dikambe u fazi rasta V7/R1, nego u fazama V2 i R2. Na osnovu ED vrednosti, oko $0,1 \%$ preporučene količine dikambe bilo je dovoljno da izazove gubitak prinosa soje od $10 \%$ kada se primjenjuje u fazi V7/R1, dok je oko 1\% preporučene količine dikambe bilo potrebno da izazove isti nivo gubitka prinosa kada se primenjuje u fazi V2 ili R2. Prema tome, kako bi se sprečio gubitak prinosa treba izbegavati zanošenje dikambe na osetljive biljke soje. Ključne reči: zanošenje dikambe, formulacija dikambe, oštećenje, Clarity ${ }^{\oplus}$, Engenia ${ }^{\circledR}, \mathrm{XtenidMax}^{\circledast}$. 